\title{
"Meninas não desenham carros... mas tem meninas que desenham": culturas infantis, relações de gênero e histórias em quadrinhos
}

\author{
Marta Regina Paulo da Silva*
}

\section{Resumo}

Este artigo discute a produção das culturas infantis a partir das experiências de meninos e meninas, de 3 a 5 anos de idade, com a linguagem das histórias em quadrinhos (HQs), tendo como foco as relaçóes de gênero. Reconhece as HQs como uma das produçóes midiáticas que interfere nos modos de viver das crianças, muitas vezes reforçando estereótipos fundados nas diferenças sexuais. Assim, em uma interlocução com a filosofia, sociologia, sociologia da infância, pedagogia da infância e arte, problematiza como as crianças se apropriam dos quadrinhos, o que deles reproduzem, inventam ou reinventam. Trata-se de um estudo de caso realizado em uma pré-escola municipal localizada na região do Grande ABC Paulista, que teve como procedimentos metodológicos: a observação e registro de campo, os relatos orais das crianças, a análise dos documentos oficiais da Rede Municipal de Educação e da pré-escola, entrevista com quadrinhista e a análise das HQs produzidas pelas crianças. Defende que meninos e meninas participam de maneira ativa na sociedade da qual fazem parte, portanto, não só reproduzem a cultura do mundo adulto, mas ao se apropriarem coletiva e criativamente desta produzem as culturas infantis. Demonstra serem as HQs parte da cultura material da infância, que se constituem em suportes para aspectos simbólicos das culturas infantis, que as crianças compartilham entre si e com os adultos e as adultas, onde se observam padróes e valores identitários sendo negociados; isso revela que elas não só reproduzem estereótipos da cultura heteronormativa, mas transgridem as fronteiras de gênero. Nesse sentido, aponta para o desafio de trazer as crianças para o debate acerca da relação "infâncias, mídia e gênero", na perspectiva de (re)conhecer como elas fruem, produzem e vão além das imagens midiáticas.

Palavras-chave: Infância. Relaçóes de gênero. Mídia.

* Doutora em Educaçáo pela Universidade Estadual de Campinas (UNICAMP). Professora do Curso de Pedagogia da Universidade Metodista de São Paulo (UMESP) e dos cursos de Pedagogia e do Mestrado em Educação da Universidade Municipal de São Caetano do Sul (USCS). 

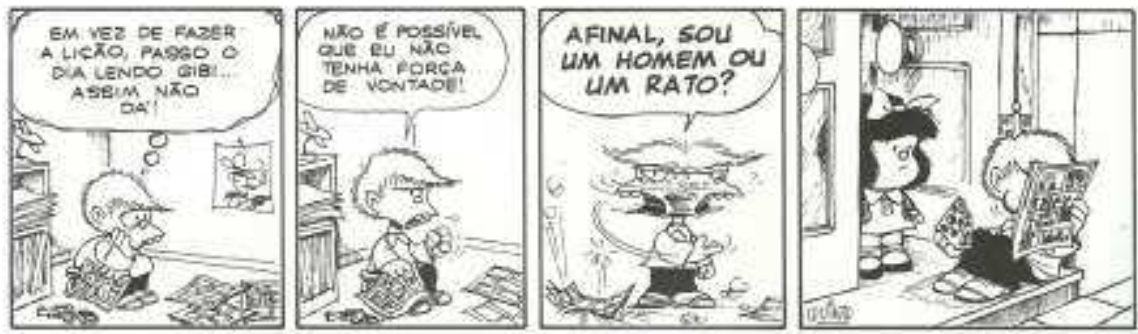

Fonte: Toda Mafalda, de Quino (2003, p. 162).

A proposta neste artigo é discutir a relaçáo entre infâncias, relaçóes de gênero e mídia, a partir das experiências das crianças pequenas com as histórias em quadrinhos (Hqs). O intuito é dar visibilidade às produçóes culturais de meninos e meninas, uma vez que, em nossa sociedade, muitos estudos terminam por subestimar a forma como as próprias crianças dão sentido às diferentes práticas culturais as quais estáo inseridas.

No caso das HQs são recorrentes os trabalhos que discutem o caráter ideológico das mesmas, por vezes apresentando-as tão somente como influências nocivas para a formação das crianças. No entanto, como discute o sociólogo e pesquisador da infância Willian A. Corsaro (2011), os estudos relativos à mídia dirigida à infância (desenho, filmes e outros) pouco investigam o papel que as imagens, personagens e histórias desempenham na vida das crianças.

Trazer as experiências das próprias crianças para este debate nos provoca a olhar curiosamente para suas produçóes e reconhecer nelas uma lógica por vezes náo compreensível ao adulto(a). É ter para com elas um olhar estrangeiro, para entáo reconhecer sua própria estrangeiridade. E, nesse sentido, não há como ser estrangeiro sem ser outro(a). Outro(a) marcado(a) pela alteridade e não pela falta, ausência ou impotência.

As crianças não são consumidoras passivas da mídia; ao contrário, em uma ação ativa sobre a mesma, meninos e meninas voltam-se curiosamente para ela e, como forma de compreender suas mensagens, muitas vezes transformam criativamente as informaçóes que recebem a fim de responder suas próprias preocupaçóes. A relação que se estabelece não é de passividade, mas de curiosidade, criação, (re)invenção.

Nessa perspectiva, apresento neste artigo parte de minha pesquisa de doutorado (SILVA, 2012), na qual investiguei a produção das culturas infantis a partir das experiências de meninos e meninas, de 3 a 5 anos de idade, em uma pré-escola municipal, com a linguagem das histórias em quadrinhos. $\mathrm{O}$ recorte feito aqui diz respeito às relaçóes de gênero, sendo esta uma das categorias que emergiu durante a pesquisa. 
Tomando as histórias em quadrinhos como um dos artefatos da mídia dirigida também às crianças, a pesquisa procurou compreender como meninas pequenas e meninos pequenos apropriam-se dos códigos da linguagem dos quadrinhos e o que deles reproduzem, inventam ou reinventam na produção de suas próprias narrativas gráficas.

Tal objetivo colocou também a necessidade de conhecer melhor as condições em que tais produçóes são elaboradas, o que implicou em examinar o cotidiano da préescola, a fim de verificar como estas se articulam na complexa rede de relaçóes sociais que neste espaço vai sendo constituída. Assim, a pesquisa procurou evidenciar os movimentos de imposição, negociação, resistência e transgressão das crianças frente às normas instituídas, uma vez que reconhece estes sujeitos como seres sociais, históricos e culturais, portanto, não apenas reprodutores, mas produtores de cultura.

Daí, a opção por uma metodologia de pesquisa que pudesse ouvir e considerar as vozes das próprias crianças. Nesse sentido, o estudo de caso etnográfico permitiu certa imersão no cotidiano da pré-escola investigada no intuito de conhecer sua dinâmica, onde foram utilizados os seguintes procedimentos metodológicos: a observação participante; os relatos orais das crianças, que não tiveram um tempo, espaço e assunto pré-determinado para acontecer, mas foram dando-se e ampliando-se à medida que os vínculos se estreitavam; o registro descritivo do campo, através da escrita, filmagem e fotografia; entrevista com o quadrinhista Laerte Coutinho; análise das HQs produzidas pelas crianças durante o projeto realizado pela professora com a turma (sendo elas: reconto/reescrita em quadrinhos da história "Os três porquinhos", produção de tiras, HQs elaboradas no caderno de desenho, e aquelas realizadas em situaçóes de desenhos livres); e análise dos documentos referentes à organização e diretrizes da Secretaria de Educação do Município e da pré-escola investigada. Todos estes procedimentos foram fundamentais para a reflexão sobre o objeto de estudo, o que permitiu construir, a partir da triangulação destas diferentes fontes no diálogo com a bibliografia de referência, interpretaçôes acerca das relaçôes observadas no campo.

A escolha da pré-escola deu-se em função da mesma desenvolver com as crianças projetos que versavam sobre as histórias em quadrinhos. A turma escolhida foi do "semi-integral", que atendia 26 crianças de 3 a 5 anos de idade e que estavam juntas em período contrário à turma "regular". Nesta turma, a professora desenvolveu um trabalho com as HQs que envolvia a exploração e leitura, o reconto/reescrita da história dos "Três porquinhos" para os quadrinhos e a produção de tiras.

Cabe ressaltar que as HQs são compreendidas neste artigo não apenas como produto de entretenimento, mas como um artefato da cultura midiática que se situa "na intersecção entre entretenimento, defesa de certas ideias políticas e sociais, prazer e 
consumo" (GIROUX, 1995, p. 60). Foco entáo nas experiências das crianças pequenas no que se refere às relaçóes de gênero, no intuito de compreender como elas se movimentam, agem, reagem, deixam seduzir-se ou náo, a partir das imagens referentes a tais relaçóes.

O desejo é de que possamos ir além da discussão do quanto os quadrinhos são pedagógicos ou não e atentarmos para as experiências que meninos e meninas possuem com este artefato midiático, e com isso contribuir na perspectiva da construçáo de outros olhares para as crianças e suas produçôes culturais; olhares mais estrangeiros.

As crianças e a produção das culturas infantis

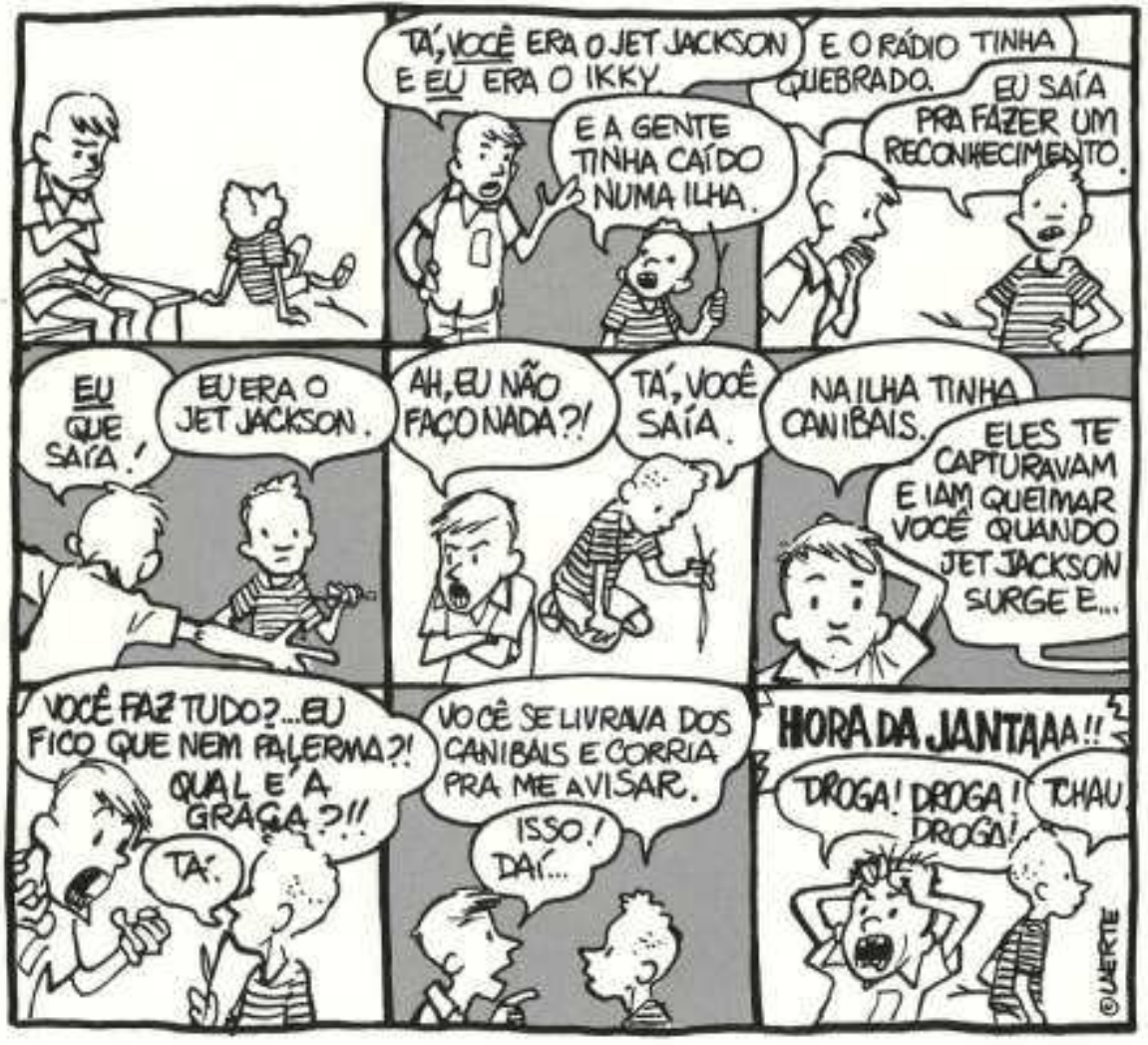

Fonte: Laertevisäo, de Laerte Coutinho (2007, p. 50). 
A compreensão da criança e da infância ao longo da História está intrinsecamente relacionada às mudanças políticas, econômicas, sociais e culturais das diferentes épocas. Por ser uma construção social, tal compreensão carrega diferentes olhares desde o lugar de quem a enuncia. Assim, as crianças foram consideradas como seres da ausência da razão, imperfeitos, fruto do pecado original, adultos em miniatura, tabula rasa, ingênuos e imaturos. Já a infância, definida como um período passageiro, como idade da natureza e, ainda, como fase de preparaçáo para a vida adulta.

Embora observemos a partir da contemporaneidade a compreensão da criança como ser sócio-histórico, pertencente a uma classe social, gênero, raça e etnia; um ser ativo e inventivo, que náo apenas reproduz a cultura, mas também a produz; na prática prevalece ainda o discurso dominante da criança como natureza pura, inocente, imatura, reprodutora de cultura, biologicamente determinada por estágios universais, e que precisa ser preparada para a vida adulta; o que termina por justificar as formas autoritárias com as quais muitos(as) adultos(as) tratam as crianças.

A infância, como tempo social vivido nos diferentes contextos que a criança participa, tem sido marcada historicamente por processos de desumanizaçáo que negam suas necessidades e direitos. Meninos e meninas não são meros seres de adaptação que estão apenas a imitar os/as adultos(as), eles(as) estấo em um processo ativo em que procuram construir sentido para as práticas culturais de que participam, e, nesse processo, coletiva e criativamente produzem as culturas infantis. Culturas estas (re)construídas a partir do mundo que os/as adultos(as) oferecem a elas, tendo por base as relaçóes de companheirismo que ocorrem, sobretudo, durante suas brincadeiras (FERNANDES, 1961) e que se manifestam através de suas múltiplas linguagens.

No que se refere às imagens, as crianças, como seres sociais, históricos e culturais, as veem, consomem e produzem. Meninos e meninas de todas as idades, e em diferentes épocas, deixaram suas marcas gráficas em cavernas, paredes, papéis, madeira, e nos mais diferentes suportes. Contudo, ainda sabemos muito pouco sobre suas produçôes a partir de seus olhares, já que a participação das crianças e suas produçóes pouco têm sido consideradas na escrita de sua história.

No entanto, é importante ressaltar que há um pensar no fazer das crianças. Estas, ao pintarem, desenharem, esculpirem, lerem, dançarem etc., demonstram que esses campos são inseparáveis. Pensar e fazer constitui, para elas, um único gesto cujo corpo testemunha o seu vivido. Como afirma Kohan (2007), o pensamento é algo lúdico, daí o motivo das crianças geralmente se entregarem a ele como que a um jogo, com seriedade e muita diversão.

Para elas não há um pensar e depois fazer, pensar e fazer não se dicotomizam. Assim, atuam curiosamente sobre os objetos de conhecimento transformando-os. Não 
há uma preocupação utilitária para aprender algo, provavelmente por isso se entreguem táo intensamente àquilo que desperta sua curiosidade, por vezes pelo puro prazer de fazê-lo. Segundo Corsaro (2011, p. 160), é por esta “razão que nós, adultos, raramente chegamos a apreciar, de verdade, a forte satisfação emocional que as crianças obtêm da produção e participação naquilo que nos parece simples jogo repetitivo".

Paulo Freire (2003), em Pedagogia do Oprimido, discute a invasão cultural como uma forma de colonialismo em que o dominador desqualifica a cultura do(a) dominado(a) e impóe sobre ele(a) sua própria cultura, tornando inautêntico o próprio ser que tem sua cultura invadida. Nesse sentido, a invasão cultural da infância se expressa pelo silenciamento das crianças, pela imposição da leitura de mundo adulta, pela negação de suas vozes e de suas múltiplas linguagens, tornando inautêntico o agir, o pensar e o sentir de meninos e meninas. Tal silenciamento dos corpos infantis retrata esta sociedade adultocêntrica que nega as culturas infantis.

Compreender o mundo a partir dos olhos das crianças implica no rompimento desse silenciamento, e, consequentemente, na construção de uma relação dialógica com elas, reconhecendo-as como participantes ativas da e na sociedade. Desse modo, é preciso olhar para as produçóes das crianças em sua potencialidade, como a capacidade que elas têm de materializar e de compartilhar suas indagaçóes frente ao mundo em que estâo inseridas, e, ao fazê-lo, deixar as marcas de sua presença. Meninos e meninas não estão apenas a incorporar, passivamente, aquilo que a sociedade lhes impóe. É preciso considerar que o processo de socialização das crianças "[...] não é só uma questão de adaptação e internalização, mas também um processo de apropriação, reinvenção e reprodução" (CORSARO, 2011, p. 31).

Assim, mais do que se adaptarem à sociedade ou imitarem os(as) adultos(as), as crianças pequenas estão em um processo em que não só reproduzem, mas também produzem culturas. Partindo daquilo que é disponibilizado para elas, vão se apropriando desses elementos através de suas brincadeiras, desenhos, falas e demais formas de expressão, e com isso criando novos e diferentes sentidos aos mesmos, o que, por sua vez, produz efeitos no "mundo adulto".

No caso das HQs, não apenas as crianças são influenciadas por elas em suas produçôes, como também influenciam o mercado e a própria produção das HQs, isto porque passaram a ganhar poder como consumidoras, embora, como discute Buckingham (2007, p. 147) ao analisar as "infâncias midiáticas", este poder tenha claras limitações, uma vez que elas "[..] só conseguem afirmar sua necessidade em relação aos serviços e produtos que os adultos lhes podem prover. Nos debates a respeito das mudanças na natureza do ensino e da oferta de lazer e de mídia, as vozes das crianças ainda são raramente ouvidas". 
Isto faz pensar quais necessidades das crianças pequenas as histórias em quadrinhos estáo a atender ou ainda a criar, sobretudo quando publicadas por grandes corporaçôes de entretenimento, em que as $\mathrm{HQ}$ são se resumem às revistas, mas a toda uma rede de produtos de consumo. Desse modo, como produto da cultura midiática, elas transitam entre as diferentes instâncias de socializaçáo, estando presentes em muitas famílias, instituiçóes educacionais e diferentes produtos da própria mídia, em que se observa a passagem de suas personagens e histórias seja das páginas das revistas em quadrinhos para as telas do cinema e/ou televisão ou vice-versa, das telas para as revistas, e mais recentemente para as páginas da internet.

\section{Histórias em quadrinhos e relações de gênero}

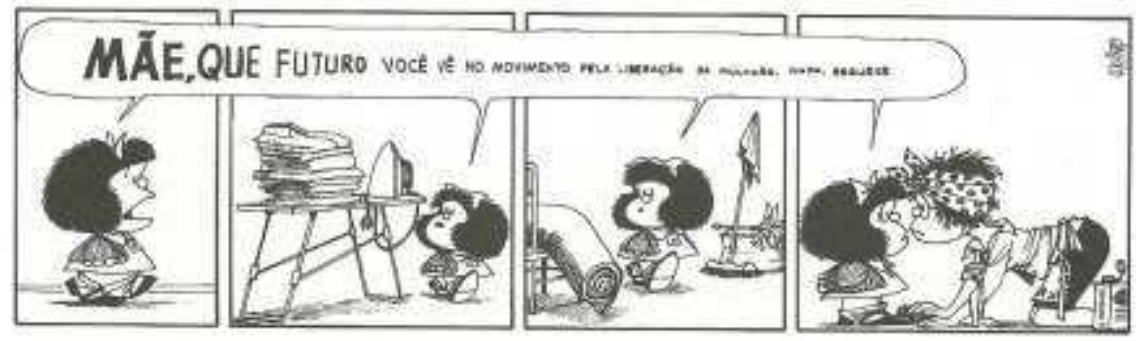

Fonte: Toda Mafalda, de Quino (2003, p. 381).

Desde bem pequenas, as crianças participam de várias práticas sociais em que vão aprendendo o que significa ser homem, mulher, branco(a), negro/(a), criança, adulto(a) etc. Nelas aprendem sobre os atributos ditos masculinos e femininos. Experimentam-nos nas relaçóes que estabelecem com outros sujeitos e com os objetos culturais. Aprendem que há uma maneira de se comportarem que é diferenciada para cada sexo. Com isso, aprendem a categorizar homens e mulheres como forma de hierarquizar e naturalizar as desigualdades sociais.

No entanto, dada à complexidade deste nosso tempo histórico, em que mudanças em diferentes campos político, econômico, social, cultural e tecnológico vêm ocorrendo, as crianças encontram-se também em meio a tantas outras experiências, que terminam por questionar os próprios valores hegemônicos. Assim, elas convivem com uma série de situaçóes diversas e, por vezes, contraditórias.

Como afirma Louro (2000, p. 104), “o lócus de construção das identidades é o corpo", desse modo, é preciso desde a infância vigiar e normalizar os corpos das crianças na tentativa de capturá-las nas formas dominantes que definem o que é ser homem ou mulher em nossa sociedade, e como cada um/uma deve comportar-se. 
Corpo que não é somente biologia, mas, também cultura, e que, portanto, está sujeito às expectativas, valores, crenças, concepçóes de cada tempo histórico, que sobre ele estabelecerá toda uma relação de poder, uma vez que "não há identidade fora do poder, todas o exercitam e, simultaneamente, todas sofrem sua açáo. As identidades fazem parte dos jogos políticos, ou melhor, as identidades se fazem em meio a relaçóes políticas" (LOURO, 2000, p. 100). As histórias em quadrinhos inserem-se neste jogo político.

História em quadrinho é um "sistema narrativo formado por dois códigos de signos gráficos: a imagem, obtida pelo desenho, e a linguagem escrita” (CAGNIN, 1975 , p. 25). São, portanto, narrativas gráficas, compostas por palavras e desenhos, que exigem de seus leitores e leitoras interpretaçóes visuais e verbais. Nelas a escrita tem uma função diferente dos livros de literatura, pois nos quadrinhos o desenho substitui, por exemplo, a descrição de cenários, as características físicas dos personagens e muitas de suas açóes. Por vezes a escrita é dispensada pelo autor ou autora. Difere ainda do livro de imagem, pois, neste caso, "é o desenho que conta a história, e o texto, quando existe, é que o ilustra” (LAGO, 2009, p. 37).

Como narrativas gráficas, as HQs veiculam formas de ser, estar e pensar o mundo. Já na década de 1970, Dorfman e Mattelart (1977) denunciavam a ideologia imperialista norte-americana contida nas histórias em quadrinhos da Disney, desde entáo é impossível compreender as HQs como uma leitura inocente, desprovida de sua dimensão ideológica. Segundo os autores, as narrativas da Disney projetam uma imagem ideal da infância, à margem de conflitos e contradições. Através delas se veiculam valores individualistas, consumistas e relaçóes sociais motivadas por interesses, sobretudo econômicos.

Essa faceta ideológica da Disney também se faz presente em outras produçôes de quadrinhos, inclusive brasileiras, onde se observa a produção de narrativas que procuram legitimar determinados valores hegemônicos acerca dos papéis sociais de homens e mulheres, que terminam por reforçar estereótipos de gênero.

Gênero é compreendido neste artigo como "[...] elemento constitutivo de relaçôes sociais fundadas sobre as diferenças percebidas entre os sexos" (SCOTT, 1990, p. 14), portanto, a maneira como cada sociedade em determinado contexto histórico estabelece relaçóes entre homens e mulheres. É, assim, uma construção social, onde cada cultura cria símbolos que evocam representaçôes simbólicas sobre o que é ser homem ou ser mulher, e como forma de limitar e conter as possibilidades metafóricas que tais representaçóes possibilitam, elabora conceitos normativos que "tomam forma típica de uma oposição binária”, e que, desse modo, vão dizer de forma categórica o sentido do masculino e feminino. Esses conceitos são produzidos e reproduzidos 
permanentemente em diferentes práticas culturais e, entre elas, estáo obviamente as HQs. Estas veiculam imagens sobre ser homem e mulher e produzem efeitos na construção da identidade de meninos e meninas, que desde pequenos(as) precisam ter seus corpos vigiados e normalizados para que se comportem segundo as expectativas e os valores heteronormativos de nossa sociedade. Assim, as histórias em quadrinhos, sobretudo aquelas destinadas ao público infantil, muitas vezes se revestem da imagem sacralizada da criança inocente, assexuada, à margem dos problemas sociais, para "despretensiosamente" produzir e reproduzir valores da classe social dominante, que deseja vender seus produtos, sejam eles bens simbólicos ou materiais.

Contudo, a própria mídia não se constitui em um sistema fechado e acabado, que encerra em si uma única possibilidade de leitura da realidade. Segundo Viana e Setton (2004, p. 97), a cultura da mídia "parece refletir de maneira ambígua relações de poder, dominaçáo e resistência, em todos os seus produtos", veiculando imagens que reificam padrôes e/ou legitimam comportamentos. Isto se observa com as HQs, onde estão em jogo, simultaneamente, diferentes discursos.

No que diz respeito à produçáo quadrinhistica destinada ao público infantil, o que se verifica é a tentativa de muitos(as) desenhistas em "fechar" as imagens, no intuito de não dar margem a diferentes interpretaçôes por parte dos(as) leitores(as). Nesse sentido, o papel da escrita torna-se fundamental, uma vez que busca diminuir a polissemia da imagem, e assim "passar" a mensagem de seus autores(as).

No entanto, as crianças não são seres passivos que absorvem o que adultos(as) disponibilizam para elas, ao contrário, são seres ativos que se voltam curiosamente para o mundo procurando compreendê-lo e assim responder às suas necessidades e preocupaçóes. Elas, portanto, leem o mundo a partir de suas próprias lentes, de suas experiências, de seu modo próprio de estar sendo no mundo.

\section{As produções das crianças a partir das HQs}

\section{Figura 1 - Tira elaborada por Suriá ( 5 anos)}

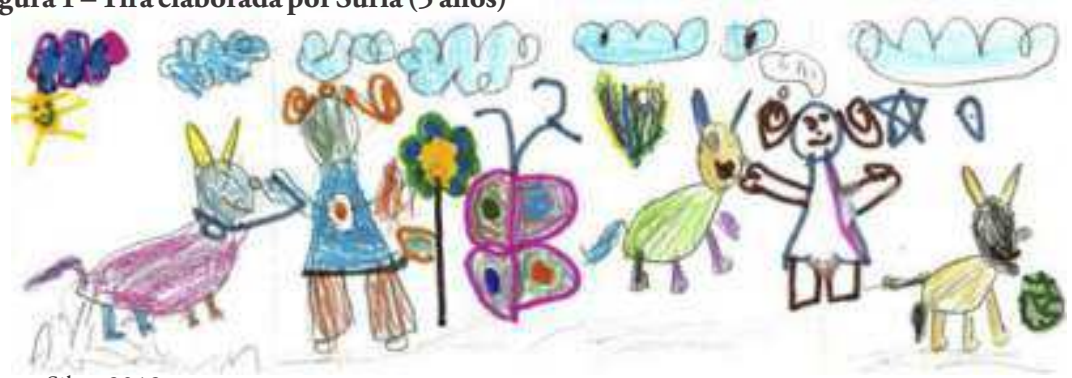

Fonte: Silva, 2012. 
Na pré-escola em que se deu a pesquisa de doutorado (SILVA, 2012), boa parte das crianças conhecia as histórias em quadrinhos, de modo especial as personagens da Turma da Mônica, do desenhista e empresário Maurício de Sousa. Pertencentes, em sua maioria, a uma classe média, meninos e meninas têm acesso não apenas aos gibis, mas também aos desenhos animados, álbuns de figurinhas, bonecos e demais artefatos que veiculam as personagens desta Turma. Isso significa dizer que, ao entrar na pré-escola, muitas já conheciam estas HQs ou ao menos suas personagens.

Na pré-escola, essas histórias fazem parte do acervo da biblioteca e das salas das diferentes turmas. Além dos gibis, há ainda reproduçôes dos "Quadrôes da Turma da Mônica”, vídeos, livros com suas personagens etc. Produçóes do quadrinhista Ziraldo também se fazem presentes na instituição, entre elas OMenino Maluquinho.

Em conversas com as crianças, muitas relataram ter HQs em casa. Nesses diálogos pôde-se verificar que pais e mães oferecem tanto para meninos quanto para meninas as HQs da Turma da Mônica; já os super-heróis (Batman, Homem Aranha, Homem de Ferro etc) parecem estar restritos aos meninos. Contudo, meninas e meninos compartilham destes personagens através de filmes e animaçóes, o que sugere um menor "controle" por parte dos(as) adultos(as) frente à mídia utilizada pelas crianças, no caso a televisão.

Ao longo da pesquisa foi possível observar o interesse das crianças pelas histórias em quadrinhos, de modo especial na ida à biblioteca da pré-escola. Neste espaço era comum pegarem as HQs, olharem, folhearem, contarem histórias, pedirem para algum(a) adulto(a) ler. Também era constante o empréstimo desse material para levarem para casa.

Em um desses momentos na biblioteca, enquanto aguardavam a professora conferir a devolução dos livros que haviam levado emprestado, meninos e meninas assistiam, a pedido da professora, ao desenho animado da Turma da Mônica (Cine Clubinho). Enquanto assistiam, travaram um diálogo onde algumas crianças diziam gostar da Mônica por ela ser divertida, outras não gostavam porque ela está sempre batendo. Em uma determinada cena do desenho, disseram que a Mônica virou uma galinha e passaram a imitar, com gestos e sons, uma galinha. A partir daí iniciaram uma brincadeira "de ser":

Linus $^{1}$ : Eusou 4 braços.

Gui: Eusouo homem defogo.

Guto: Sou o homem de gelo.

Lucy: Menina gelo.

Filipe: Também menino de 4 brą̧os.

Marcie: Menina de gelo.

Charlie: Ea Marta?

Filipe: Elaéa supermaravilha e o Miguelitoéo Ben 10. 


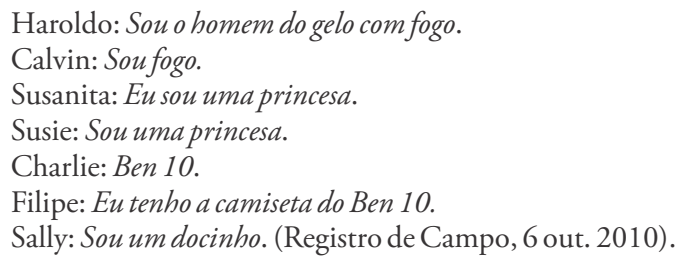

A partir de uma cena do desenho, em que Mônica "vira uma galinha", as crianças criam um jogo verbal em que elas "viram" personagens, fazendo referência aos contos de fadas, como a princesa, e aos desenhos animados e HQs, como Ben 10 (4 braços, homem defogo), Mulher Maravilha (supermaravilha) e as Meninas Super Poderosas (docinho). Aqui, as crianças distanciam-se das personagens da Turma da Mônica e trazem para sua brincadeira outras personagens que se encontram, sobretudo, nos desenhos animados.

Esta brincadeira de "ser" outra pessoa ou personagem é bastante comum entre as crianças pequenas. Neste jogo de papéis, meninos e meninas improvisam e se divertem ao mesmo tempo em que reconhecem o poder transformador da brincadeira. Ao fazerem uso de tal poder, terminam por ampliar o contexto em que determinados papéis sociais se inserem (CORSARO, 2009), sejam estes papéis de pai, mãe, professora, princesa, ou ainda de super-heróis.

Observamos nesta brincadeira das crianças uma identificação das meninas tanto com as princesas quanto com as heroínas do desenho As Meninas Super Poderosas, e ainda com Ben 10, atribuindo seu poder de transformação a uma menina, o que parece demarcar que as meninas têm poderes, assim como os meninos. Isso nos leva a pensar que boa parte das meninas resiste ao papel historicamente atribuído às mulheres como seres frágeis, indefesas e submissas; as personagens escolhidas por elas são revestidas de força e poder. Em outros momentos da observação de campo, pudemos verificar que algumas meninas preferem personagens que associam força e beleza, quando, por exemplo, dizem gostar de Sakura, personagem feminina das histórias do Naruto, "porque ela éforte e bonita".

Assumir esses papéis em suas brincadeiras, pode estar associado ao desejo das crianças em conquistar certa autonomia frente à autoridade do(a) adulto(a), e, assim, como diz Corsaro (2011), obter, durante esses momentos, o controle sobre suas próprias vidas. Para Jones (2004), personagens como os de super-heróis são símbolos de força e quando as crianças brincam de ser um desses personagens se sentem também fortes.

Do universo dos super-heróis, Batman e Homem Aranha são os preferidos, o que faz com que pedaços de tecido se transformem em capas, máscaras sejam pintadas de 
preto fazendo referência ao "homem morcego", teias de aranha sejam lançadas das mãos das crianças sobre os objetos e supostos vilóes. Nessas brincadeiras observamos que eram apenas os meninos que brincavam, o que parece reafirmar ser tais histórias destinadas ao universo masculino.

Assim, Naruto, Ben 10, Transformers, Batman, Homem Aranha, Meninas Super Poderosas, Pucca, entre outros, invadem o parque e demais espaços da pré-escola através das brincadeiras das crianças. Há aqui um empoderamento destas, uma vez que podem experienciar diferentes papéis, assumindo certo status referente ao poder e controle.

No caso das meninas, tal empoderamento, através destas personagens, ocorre de forma mais tímida. As iniciativas no parque acontecem geralmente longe dos olhares dos(as) adultos(as), o que sugere que estas brincadeiras para as meninas não são aceitas por parte destes(as), reforçando desde a infância práticas sexistas que definem haver brincadeiras específicas para os meninos e brincadeiras específicas para as meninas.

No entanto, as meninas transgridem a estes padróes de gênero e assim vemos heroínas escalando o trepa-trepa do parque, agora transformado em um prédio, voando, ou ainda escondendo-se para então surpreender, entre os espaços imaginários de suas histórias, os vilóes e vilãs, demonstrando, assim, que as crianças não aceitam passivamente os estereótipos referentes ao gênero, mas os desafiam e refinam. É o caso, por exemplo, de Suriá (5 anos):

No parque, Felipe e Miguelito brincavam de luta, onde corriam, escondiam-se entre os brinquedos e voltavam a aparecer, de modo a tentar surpreender um ao outro. De repente, Felipe finge acionar o que parecia ser seu relógio, possivelmente uma menção do desenho do Ben 10. Grita "chama", e faz movimentos mais velozes como se estivesse se transformando em um dos alienígenas do Ben 10. Miguelito corre e logo ele também aciona o seu relógio imaginário, e ambos, agora alienígenas correm, escondem-se e tentam atingir um ao outro com suas possíveis chamas. Suriá, que observava a brincadeira também aciona o provável relógio e sai a correr e a ser perseguida pelos dois alienígenas, ela própria também um. (Caderno de campo, nov. 2011).

Nessa brincadeira, Suriá assume uma personagem "masculina” e integra-se na brincadeira iniciada pelos meninos, que a aceitam sem qualquer problema, e durante um bom tempo permanecem brincando juntos(as). Finco (2004), ao observar as relaçôes de gênero nas brincadeiras de meninos e meninas em uma pré-escola, verificou não haver entre essas crianças práticas sexistas em suas brincadeiras e que, portanto, não reproduzem o sexismo presente no mundo adulto. Constatou também que as formas de 
agrupamentos entre as crianças são as mais variadas possíveis, o que coloca em questão pesquisas que naturalizam tais agrupamentos.

Em suas brincadeiras, as crianças estão mais livres do olhar dos(as) adultos(as), permitindo-se experimentar os diferentes papéis. No que se refere às questóes de gênero, demonstram que "nada há de puramente 'natural' e 'dado' em tudo isso: ser homem e ser mulher constituem-se em processos que acontecem no âmbito da cultura" (LOURO, 2008, p. 18).

Ainda sobre a brincadeira "de ser" das crianças, interessante observar que elas atribuíram à pesquisadora uma personagem adulta e mais antiga (Mulher Maravilha), o que sugere o contato das mesmas com esta personagem, seja através dos desenhos animados veiculados pela televisão, revistas em quadrinhos, ou ainda conversas com os(as) adultos(as).

Sobre este encontro entre adultos(as) e crianças, no que se refere aos desenhos animados, Fernandes e Oswald (2003), em pesquisa realizada com crianças com faixa etária entre 9 e 10 anos, demonstram como o momento de assistir desenhos juntos, adulto(as) e crianças, pode constituir-se em um "encontro de alteridades", visto que, nesta relaçáo com desenhos, náo há uma criança que náo sabe e um adulto que tudo sabe, concepção esta que ainda habita o imaginário de tantas pessoas.

Para Buckingham (2007), esta relação adulto(a), criança e mídia têm duas faces que precisam ser consideradas. De um lado, aponta que as fronteiras parecem estar se diluindo, visto que com as novas tecnologias da mídia hoje as crianças têm acesso a materiais antes restritos aos adultos(as); por outro lado, acredita que outras fronteiras estão sendo reafirmadas, pois o aumento do acesso das crianças a estas tecnologias possibilita a elas não ler ou assistir mais o que os pais e mães escolhem, restringindo-se às mídias produzidas especificamente para elas, que em muitos aspectos são excludentes para os(as) adultos(as).

Quanto a este encontro, tendo como sujeito as crianças pequenas, entre 0 e 6 anos, há uma lacuna em termos de pesquisa. Segundo Corsaro (2011), pouco se sabe como as crianças negociam o acesso à mídia, ou ainda como se comunicam com seus pais/mães e até mesmo entre seus pares sobre aquilo que veem na mídia.

Durante a pesquisa de campo, não observamos a presença das personagens da Turma da Mônica nas brincadeiras das crianças. Estas aparecem geralmente em conversas entre as crianças, seja no contato direto com os gibis e desenhos animados, ou ainda através de outros objetos que veiculam a imagem de suas personagens, tais como brinquedos, roupas etc.

Nessas conversas é comum referências ao fato da Mônica estar brava e sempre bater nos meninos, de modo especial no Cebolinha. Por vezes, algumas meninas 
procuram justificar a brabeza da personagem alegando que os meninos estão sempre aprontando com ela, querendo pegar seu coelhinho, porém, não há por parte delas uma defesa explícita à atitude da personagem. Alguns meninos, por outro lado, não gostam da Mônica, justamente porque ela bate nos personagens meninos; alguns dizem gostar do Cebolinha, pois ele está sempre elaborando planos, mesmo que estes não deem certo.

Cabe observar que, embora líder da Turma, não é Mônica aquela que cria estratégias que possam reunir a turma; este papel é do Cebolinha, no coletivo dos meninos, são eles que criam planos "infalíveis" e dão certo dinamismo às histórias, e isto parece claro para alguns meninos da pré-escola pesquisada. Tais planos parecem dar certo a princípio, porém náo se efetivam, isso porque um dos próprios meninos da turma sempre termina por se entregar. Não é Mônica quem descobre e desmascara os meninos, o que nas histórias parece sugerir pouca astúcia da personagem. Mônica usa a força, mas não a inteligência para lidar com os meninos.

Em vários momentos do trabalho de campo, pudemos acompanhar conversas entre as crianças em que os meninos diziam serem mais rápidos ou mais fortes do que as meninas, e em todos esses momentos as meninas discordavam dos meninos apresentando argumentos em suas defesas, como vemos no diálogo abaixo, estabelecido entre as crianças e pesquisadora a partir de uma HQ do Laerte, que levou para turma por solicitação da professora. Optou por levar uma história de um quadrinista que gosta, o Laerte. A escolha da HQ também teve como critério a presença de pouco texto escrito, no intuito de que as crianças pudessem inventar suas próprias histórias, e como a tira (Figura 2) poderia provocar uma discussão sobre as questôes de gênero.

Figura 2-HQ do Laerte Coutinho

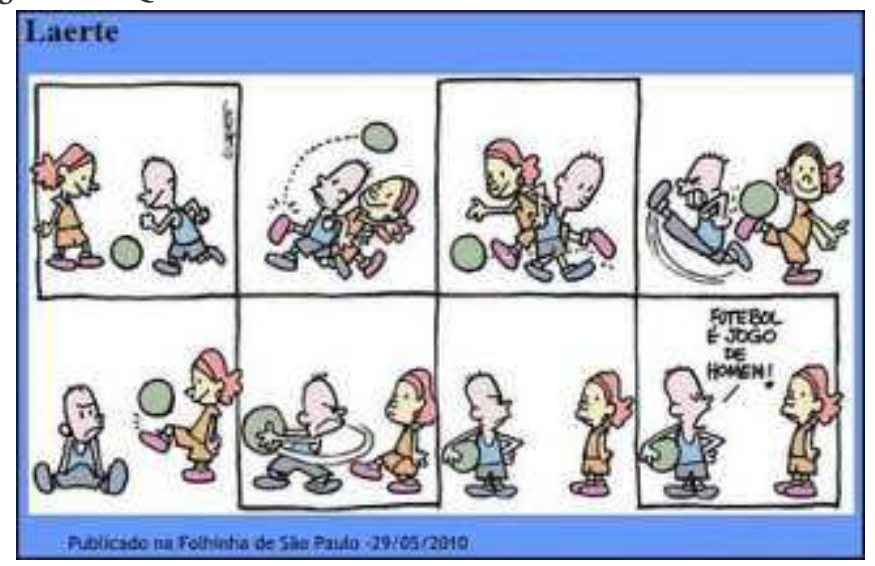

Fonte: Folhinha de São Paulo, 29 maio 2010. 
[...] Nesse momento começaram uma discussão acerca das meninas saberem ou náo jogar futebol. Tudo começou quando Manolito (6 anos) deu risada e disse que as meninas náo sabem jogar bola. Alguns meninos endossaram sua fala, dizendo que as meninas são fracas e não correm muito. Lola (5 anos) revidou, afirmando que as meninas sabem sim e que tem mulher que joga bola. Outras falaram que viram na televisão o jogo das mulheres. Os meninos trouxeram que têm mais futebol de menino. Os meninos imitavam jogadas de futebol, as meninas punham-se na frente tentando argumentar que também sabiam, até que Manolito afirmou: “Tá bom, elas podem jogar futebol, mas só se for no campo de menina”. A atividade foi interrompida, pois era horário do almoço e as crianças tinham que se dirigir ao refeitório. (Registro de Campo, 15 jun. 2011, grifo da autora).

Apesar de limitados em muitos momentos pelo tempo das atividades, é interessante observar como Manolito foi revendo sua posição durante a discussão, sobretudo pela reação das meninas, embora ainda tenha permanecido numa atitude de que então as meninas "podem jogar, mas só se for no campo de menina”, o que parece reproduzir práticas esportivas presentes em nossa sociedade, em que homens e mulheres jogam futebol separados; ou ainda, no caso das crianças, em que muitas pré-escolas oferecem curso de futebol para meninos e balé para meninas, além do destaque dado pela mídia ao futebol masculino. Em outros momentos, com novas leituras, novas significaçóes foram dadas a HQ (Figura 2), entre elas, o reconhecimento de alguns meninos de que "ela era melhor no futebol".

Com isso, observamos que as crianças pequenas estão a (re)pensar os papéis sociais de menino e menina, confrontando, muitas vezes, ideias, valores e práticas culturais que procuram insistentemente reafirmar que existe um único jeito "natural" de ser homem ou mulher, o que demonstra que elas não apenas incorporam os estereótipos de gênero, mas nas interaçóes entre elas e também com os(as) adultos(as) as ressignificam, o que indica que as expectativas referentes ao gênero não são simplesmente inculcadas nas crianças, mas são socialmente construídas por elas nas interaçóes (CORSARO, 2009).

Além das brincadeiras, o universo das HQs também se faz presente nos desenhos de meninos e meninas. Segundo Staccioli (2011, p. 32), "os desenhos das crianças são o espelho de seus pensamentos. E os pensamentos refletem, em parte, as sugestóes que as crianças recebem". Sugestóes oriundas das mais diferentes fontes: família, instituiçóes educacionais, religiosas, mídias etc.

Para o quadrinhista Laerte Coutinho ${ }^{2}$, o desenho era "uma espécie de vingança” contra os finais das histórias que ele gostava: 
Toda história vem da história. Eu comecei a fazer história na aflição de gozar mais das histórias que eu curtia, dos quadrinhos mesmo, da televisão, ou coisas contadas. O quadrinho, o desenho... não sei, esta é uma análise que faço hoje, para mim deve ter funcionado por este poder extraordinário que é você fazer sozinho aquilo, traduzir aquela mágica que produzem pra você. Então desenhar é de alguma maneira você superar o fim daquela história. [...]. Desenhar para mim era uma espécie de vingança, eu conseguia continuar a história, [...] elaborava fazendo outras histórias, ou redesenhando coisas, principalmente filmes; lembro que chegava em casa e desenhava, redesenhava, reelaborava, os quadrinhos e tudo que caía na minha mão.

Assim, meninos e meninas trazem para suas produçóes aspectos do contexto histórico cultural do qual participam. Daí apresentarem cenas do cotidiano, de brincadeiras, filmes, desenhos animados, contos etc. Referências que também passam pela forma como desenham: os traços, linhas, cores, que, por sua vez, são marcados por ideias e valores que circulam na sociedade em que vivem. Passam ainda, pela forma como os(as) adultos(as) olham e valorizam suas produçôes.

Nessa perspectiva, ao observar, a partir dos dados da pesquisa, as tiras de HQs produzidas pelas crianças em seu conjunto, tomando como foco os assuntos que escolheram para comporem suas narrativas, verificamos que a maioria das tiras das meninas traz como tema central personagens mulheres, apenas uma menina desenhou também um personagem homem representando um pai. As cenas geralmente remetem aos cuidados com os animais e com as irmãs, ter uma casa, ter um pai. São presentes representaçóes de flores, borboletas, casas, animais e coração (Figura 3).

\section{Figura 3 - Tira elaborada por Susie (4 anos)}
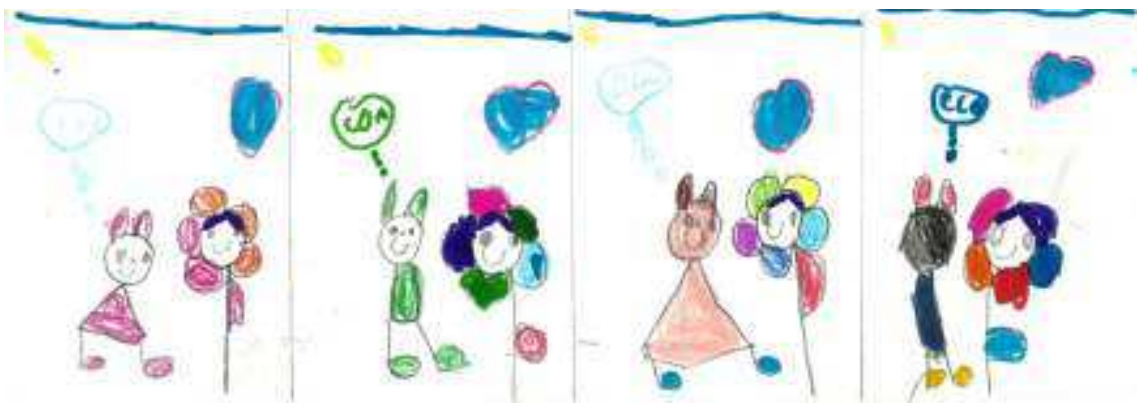

Fonte: Silva, 2012. 
Nas tiras dos meninos encontramos carros, personagens de filmes e desenhos animados, jogos eletrônicos e brincadeiras. Representaram situaçôes de meninos brincando, carros se transformando em robôs (Figura 4), jogos e heróis salvando o planeta.

\section{Figura 4 - Tira elaborada por Gui (5 anos)}
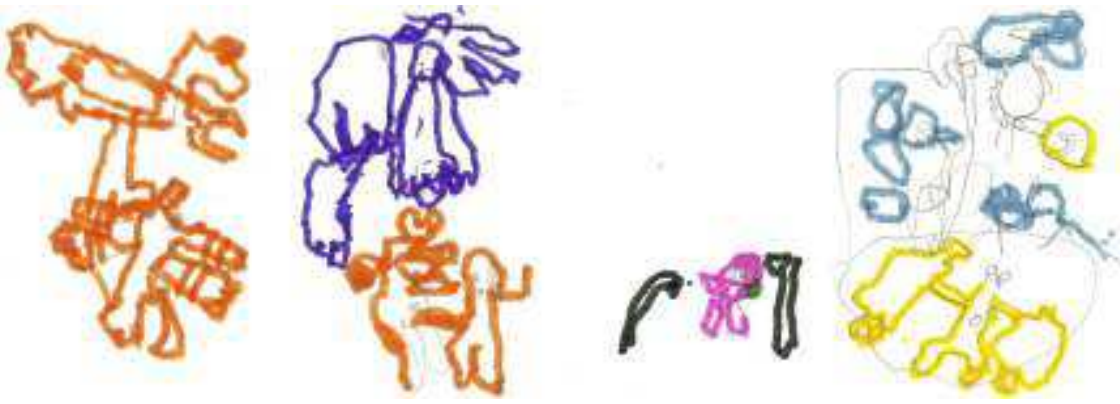

Fonte: Silva, 2012.

Belotti (1979), na década de 1970, observou a presença e a permanência desses temas entre as crianças, onde verificou que os desenhos das meninas eram quase exclusivamente relacionados à vida familiar; já os dos meninos, em sua maioria, descreviam cenas com carros, policiais, ladrôes, dentre outros personagens masculinos, junto com personagens imaginários como príncipes, feiticeiros ou fantasmas.

Para a autora, tais representaçóes demonstram como são educadas(os) meninas e meninos desde bem pequenas(os); as primeiras mais presas ao interior da casa e à companhia da mãe; os segundos mais livres, mais fora de casa em grupos de amigos, sem preocupaçóes com os afazeres domésticos. Portanto, educados(as) com diferentes expectativas quanto aos seus papéis sociais.

Assim como Bellotti (1979), Gobbi (1997) também verificou a reiteração de símbolos que demarcam as fronteiras entre masculino e feminino nos desenhos das crianças. No entanto, a partir dos dados de sua pesquisa de mestrado, demonstrou ser aquele momento (final da década de 1990), um período de "transição nas relaçóes mantidas entre homens e mulheres, na concepção que têm das mesmas e na própria construção das relaçôes de gênero" (GOBBI, 1997, p. 136), em que verificou mudanças nos papéis sociais de homens e mulheres no interior das famílias das crianças.

Na pesquisa utilizada neste artigo (SILVA, 2012), o modo como esses temas se distribuem entre meninos e meninas denota a presença de estereótipos de gênero em suas produçôes, porém foi possível também identificar algumas mudanças, como é o 
caso, por exemplo, de Suriá (5 anos), que desenhou o Ben 10 e várias vezes desenhou carros; ela que, em uma determinada ocasião, ao reconhecer o desenho de Filipe disse: "parece os desenhos dele, as meninas não desenham carros, mas têm meninas que desenham".

Suriá observa que geralmente as meninas não desenham carros, mas há meninas, como ela própria, que desenham. Ao tentar compreender com ela porque isso ocorre, disse que as meninas não gostam de desenhar carros, preferem desenhar princesas. Quanto a ela, gosta "de desenhar tudo que vem na sua cabę̧a”. A produçáo de Suriá e sua fala sugerem que, para ela, os papéis atribuídos aos homens e mulheres não são tão fixos; isso também se verifica no parque onde brinca tanto com meninas quanto com meninos, representando em suas brincadeiras diferentes papéis, seja de dona de casa, seja de super herói. Charlie ( 5 anos) parece também não ter problema em desenhar uma heroína das animações (Figura 5), segundo ele tanto homens como mulheres podem assumir este lugar.

\section{Figura 5 - Tira elaborada por Charlie (5 anos)}
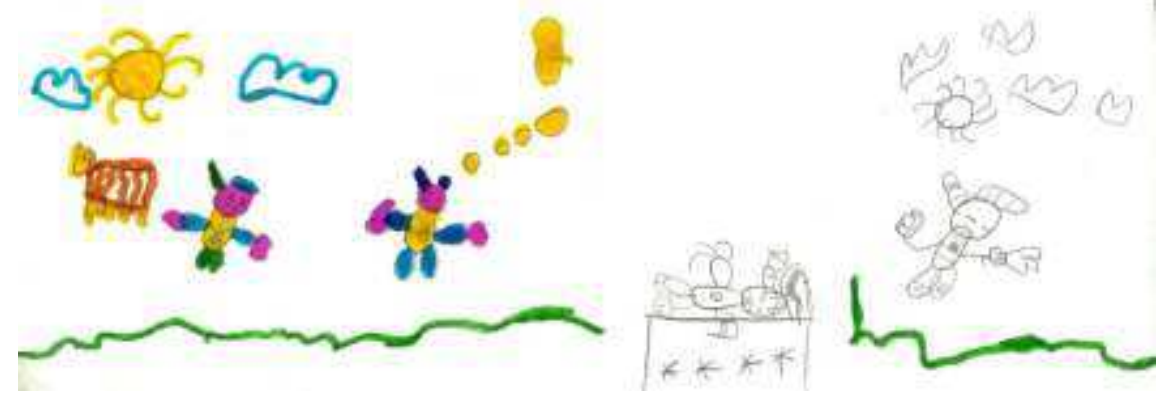

Fonte: Silva, 2012.

Outra transgressão se observa nos desenhos dos meninos, entre eles Charlie e Gui, que ao desenharem o Ben 10, Transformers, Jenny, Batman, dentre outros, procuram cuidar dos detalhes, o que fazia com que geralmente náo conseguissem terminar no tempo estipulado pela professora para aquela atividade. Nesses momentos, os meninos procuravam esticar um pouquinho mais o tempo, solicitando à docente, ou simplesmente ficando na atividade mesmo quando sua turma já se dirigia para outros espaços da pré-escola, por vezes utilizavam da presença da pesquisadora para que ficasse com eles na sala enquanto terminavam, o que era permitido pela professora.

Esta atenção aos detalhes póe em suspense a ideia recorrente de que as "meninas são mais caprichosas" em seus desenhos, enquanto os "meninos fazem tudo correndo, sem capricho". Assim, diferente do discurso de que as meninas ficam mais 
concentradas, que seus desenhos apresentam mais detalhes em comparação ao dos meninos, nesta turma não se observou isto. As crianças, quando envolvidas nas atividades, quando estas pareciam ter algum sentido e despertavam seu interesse, entregavam-se com todo o seu corpo a estas produçóes.

Nas histórias contadas pelas crianças, sejam de suas próprias HQs ou a partir da leitura das HQs dos amigos e amigas, verificam-se narrativas em que se articulam diferentes informaçóes provenientes do universo que adultos(as) apresentam aos meninos e meninas. Nelas, observam-se também mudanças e permanências quanto aos papéis sociais relativos às relaçôes de gênero, como é o caso, por exemplo, da HQ "Boneca sem dono", elaborada por Marieta (Figura 6) e, posteriormente, lida por Marion (3 anos).

\section{Figura 6 - Tira elaborada por Marieta (5 anos)}

Fonte: Silva, 2012.

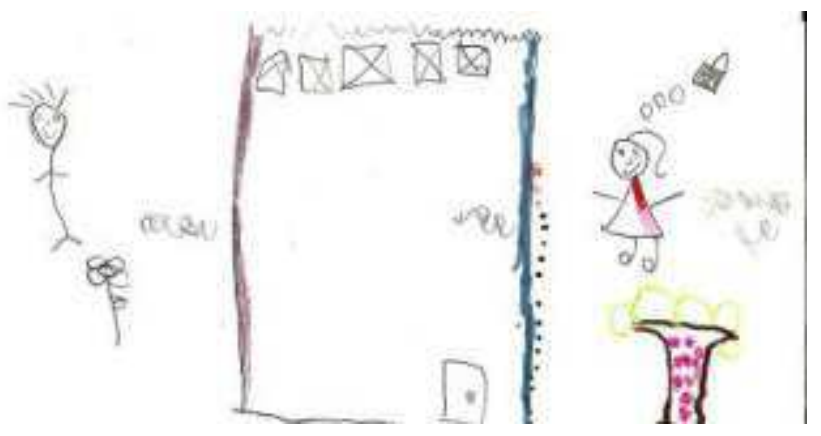

Era uma vez uma menininha perdida, e ela se casou com o menino, ai ela abriu a porta da casa, ai tinha um cachorro, ai ele saiu para fora, ai depois ela se casou e a menininha não queria se casar e depois ela abriu a janela e o monstro entrou e ai ele voou com a vassoura, ai o monstro brigou com ela, ai ela estava tão forte que ela batia no monstro, ai ela colocou o brinco dela de novo, ai ela abriu a janela, mas ela náo conseguiu abrir. (Marion, 3 anos).

A história de Marion possibilita-nos pensar várias questôes. Primeiro, a presença de cenas voltadas ao cotidiano da casa com aquelas provenientes dos contos de fadas, em uma articulação que demonstra a tensão da personagem ("a menininha”) que casou, mas náo queria casar, que é forte a ponto de bater no monstro que entra em sua casa, mas que quando coloca o brinco parece perder a força e não consegue abrir a janela.

A partir de sua narrativa é possível uma série de interpretaçóes que sugerem que ela, assim como outras crianças, procura compreender e ressignificar valores e normas 
sociais provenientes das diferentes instâncias de socialização. Para Setton (2005, p. 345):

[...] à medida que os universos de referências sociais e identitários compartilhados se multiplicam e se diversificam, à medida que uma pluralidade de opçóes e escolhas está ao alcance dos indivíduos, estes terão, consequentemente, cada vez mais oportunidades de deliberar. Nesse caso, os atores sociais não se reduziriam a uma identificaçáo coerente com papéis sociais e identitários e com padrôes normativos institucionais atribuídos a eles, nem interiorizariam linearmente projetos institucionais, mas articulariam uma gama variada de padróes e valores identitários.

Desse modo, cenas do cotidiano das crianças, os contos de fadas, as novelas, os jogos eletrônicos, os filmes, os desenhos, as HQs, enfim, uma profusáo de imagens e sons vão se constituindo em referências para meninos e meninas no complexo processo de constituição das suas identidades.

Nesse sentido, as instituições atuais de socialização, também provocadas e questionadas pelos diferentes movimentos sociais, não estão tão somente a condicionar as crianças aos estereótipos masculino e feminino, e mesmo quando o desejam, deparam-se com seres curiosos e pensantes, que, por um lado, constrangidos frente às pressôes sociais de uma sociedade machista reproduzem estereótipos de gênero, por outro lado, resistem a estas "fôrmas".

Como discute Butler (2010, p. 154), os corpos "não se conformam, nunca, completamente, às normas pelas quais sua materialização é imposta”. Daí ser necessária toda uma "prática reiterativa e citacional pela qual o discurso produz os efeitos que ele nomeia”. A repetição de um signo e sua citacionalidade, ou seja, sua capacidade de ser citado independentemente do contexto em que foi gerado, faz com que este continue sendo inteligível e produtivo. Com isso, para que produza efeitos sobre os corpos, é necessário, como afirma Sabat (2007, p. 156), "que seja produzida toda uma rede de significantes interligados", reafirmando e naturalizando suas representaçóes.

No caso da cultura simbólica destinada à infância, esta rede se dá através da produção e veiculação dessas representaçóes ao mesmo tempo em filmes, desenhos animados, histórias em quadrinhos, propagandas, livros, álbum de figurinhas, brinquedos e a imagem das personagens em uma infinidade de outros produtos a serem consumidos.

Brougère (1997), ao discutir as brincadeiras, afirma que as crianças brincam com o que têm na mão e na cabeça. $\mathrm{O}$ mesmo se pode dizer em relação às suas histórias e 
aos seus desenhos, onde todas suas experiências são suportes para a imaginação, o que possibilita a estas ultrapassarem, muitas vezes, os limites das "fôrmas" com as quais os discursos e práticas adultocêntricas e sexistas procuram enquadrá-las.

Assim, embora semióticas dominantes tentem as aprisionar desde bem cedo, como denuncia Guattari (1981), as crianças pequenas ao agirem sobre elas não só reproduzem tais códigos como a eles agregam novos elementos e significados.

\section{Considerações finais}

Ao longo de toda a pesquisa foi possível verificar que as crianças pequenas, em todas as suas produçóes, estão pensando; suas escolhas não são aleatórias. Há escolhas, gestos em que fazer e pensar são se separam. Mesmo em situaçóes mais dirigidas pela professora, através de suas experimentaçóes imprimem suas marcas, sua compreensão poética nas formas de ver, pensar, sentir e dizer o mundo.

Nessa perspectiva, em suas experiências com as HQs, meninos e meninas estão pensando e discutindo os papéis assumidos por homens e mulheres, ora reproduzindo falas, gestos e imagens, que apontam para a manutenção dos discursos hegemônicos acerca das relaçôes de gênero, ora transgredindo-os. Nesse processo, fica claro que muitos quadrinhos contribuem com a produção e veiculação de modelos hegemônicos de identidades de gênero, embora por si só não tenham o poder de inculcar tais modelos sobre as crianças pequenas, assim como nenhuma outra mídia. Isso porque, as crianças são seres sociais, históricos e culturais e, embora se observe em suas produçóes reproduçóes de aspectos da cultura heteronormativa, ao mesmo tempo verificam-se movimentos de resistências a esta, em que demonstram, sobretudo no coletivo, curiosidade e inventividade, revelando, desse modo, aspectos presentes nas culturas vividas e produzidas por elas.

Dessa forma, o convívio das crianças na educação infantil pode constituir-se em experiências importantes na compreensão desses papéis, onde, coletivamente, elas mostram sua capacidade de resistirem e transgredirem as "fôrmas" homogêneas de ser e estar no mundo. Quanto as HQs, estas não são apenas formas de distraçóes inúteis; mas, ao contrário, constituem-se em suportes para aspectos simbólicos das culturas infantis que as crianças compartilham entre si, com suas famílias e também com professores(as), em que se observam padróes e valores identitários sendo negociados, revelando, assim, que as crianças não só reproduzem estereótipos, mas transgridem as fronteiras de gênero.

Concordando com Giroux (1995), pensamos que as instituições educacionais devam não apenas reconhecer a importância dos produtos culturais que as crianças 
trazem para dentro desses espaços, no caso deste estudo as HQs, mas que trabalhem com elas na perspectiva de que as crianças, além de analisar as representaçôes da cultura, possam também produzi-las. Será junto a e com as crianças que nós adultos(as) vamos poder compreender como elas se apropriam, interpretam e recriam os conteúdos destas histórias produzindo deste modo as culturas infantis.

\section{Notas}

${ }^{1}$ No intuito de preservar a identidade das crianças, seus nomes foram substituídos por nomes de personagens de Hqs.

${ }^{2}$ Entrevista com Laerte Coutinho realizada por Marta Regina Paulo da Silva. São Paulo, 2011.

\section{REFERÊNCIAS}

BELOTTI, Elena Gianini. Educar para a submissão. 2. ed. Petrópolis, RJ: Vozes, 1979.

BROUGÈRE, Gilles. Brinquedo e cultura. 2. ed. São Paulo: Cortez, 1997. (Coleção Questóes da nossa época, v. 43).

BUCKINGHAM, David. Crescer na era das midias eletrônicas. São Paulo: Loyola, 2007.

BUTLER, Judith. Corpos que pensam: sobre os limites discursivos do "sexo". In: LOURO, Guacira Lopes (Org.). O corpo educado: pedagogias da sexualidade. 3. ed. Belo Horizonte: Autêntica, 2010. p. 151-172.

CAGNIN, Antônio L. Os quadrinhos. São Paulo: Ática, 1975.

CORSARO, William A. Métodos etnográficos no estudo da cultura de pares e das transiçôes iniciais na vida das crianças. In: MÜLLER, Fernanda; CARVALHO, Ana Maria A. (Org.). Teoria e prática na pesquisa com crianças: diálogos com William Corsaro. São Paulo: Cortez, 2009. p. 83-103.

CORSARO, William A. Sociologia da infância. 2. ed. Porto Alegre: Artmed, 2011. COUTINHO, Laerte. Laertevisão. São Paulo: Conrad, 2007.

DORFMAN, Ariel; MATTELART, Armand. Para ler o Pato Donald: comunicação de massa e colonialismo. Rio de Janeiro: Paz e Terra, 1977. 
FERNANDES, Florestan. Folclore e mudança social na cidade de São Paulo. São Paulo: Anhambi, 1961.

FERNANDES, Adriana H; OSWALD, Maria Luiza. Ressignificando as relaçóes adulto/criança na contemporaneidade: "prefiro ver televisão sozinha porque os adultos só entendem dos desenhos da época deles”. Série Educação, Rio de Janeiro, v. 63, p. 1-18, 2003.

FINCO, Daniela. Faca sem ponta, galinha sem pé, homem com homem, mulher com mulher: relaçôes de gênero nas brincadeiras de meninos e meninas na pré-escola. 2004. Dissertação. (Mestrado em Educação) -Universidade Estadual de Campinas, Campinas, SP, 2004.

FREIRE, Paulo. Pedagogia do oprimido. 35. ed. Rio de Janeiro: Paz e Terra, 2003.

GIROUX, Henry. A disneyzação da cultura infantil. In: SILVA, Tomas Tadeu da; MOREIRA, Antonio Flávio (Org.). Territórios contestados: os currículos e os novos mapas políticos e culturais. Petrópolis, RJ: Vozes, 1995. p. 49-81.

GOBBI, Márcia Aparecida. Lapis vermelho é de mulherzinha: desenho infantil, relaçôes de gênero e educação infantil. 1997. Dissertação (Mestrado em Educação) Universidade Estadual de Campinas, Campinas, SP, 1997.

GUATTARI, Félix. As creches e a iniciação. In: GUATTARI, Félix. Revolução molecular: pulsaçóes políticas do desejo. São Paulo: Brasiliense, 1981. p. 50-55.

JONES, Gerard. Brincando de matar monstros: porque as crianças precisam de fantasia, videogames e violência de faz-de-conta. São Paulo: Conrad, 2004.

KOHAN, Walter O. La edad de los porquês: entrevista com Walter Kohan. Diario de Cuyo.com, 2007. Disponível em: <http://www.serpadres.es/3-6-anos/educacion-ydesarrollo/la-edad-de-los-porques.html>. Acesso em: 15 set. 2012

LAGO, Angela. Ponte das intencionalidades. In: GÓES, Lúcia Pimentel; ALENCAR, Jackson (Org.). Alma da imagem: a ilustraçáo nos livros para crianças e jovens na palavra de seus criadores. São Paulo: Paulus, 2009. p. 35-45. (Coleção Pedagogia e Educação).

LOURO, Guacira Lopes. Currículo, gênero e sexualidade. Porto: Editora Porto, 2000. (Coleção Currículo, políticas e práticas).

LOURO, Guacira Lopes. Gênero e sexualidade: pedagogias contemporâneas. ProPosiçôes. Campinas, SP, v.19, n. 2, p. 17-23, maio/ago., 2008.

QUINO. Toda Mafalda. São Paulo: Martins Fontes, 2003. 
SABAT, Ruth. Gênero e sexualidade para consumo. In: LOURO, Guacira Lopes; FELIPE, Jane; GOELLNER, Silvana Vilodre (Org.). Corpo, gênero e sexualidade: um debate contemporâmeo na educação. 3. ed. Petrópolis, RJ: Vozes, 2007. p. 149-159. SETTON, Maria da Graça J. A particularidade do processo de socialização contemporânea. Tempo Social, São Paulo, v. 17, n. 2, p. 335-350, nov. 2005. SCOTT, Joan Wallach. Gênero: uma categoria útil de análise histórica. Educação e Realidade, Porto Alegre, v. 16, n. 2, p. 5-22, jul./dez. 1990.

VIANNA, Cláudia Pereira; SETTON, Maria da Graça Jacintho. O conceito de gênero e a construção dos sujeitos femininos na família: o uso do cinema nas reflexôes educacionais. In: SETTON, Maria da Graça Jacintho (Org.). A cultura da mídia na escola: ensaios sobre cinema e educação. São Paulo: Annablume, 2004. p. 83-100.

SILVA, Marta Regina Paulo da. Linguagem dos quadrinhos e culturas infantis: "é uma história escorridinha”. 2012. Tese (Doutorado em Educação) -Universidade Estadual de Campinas, Campinas, SP, 2012.

STACCIOLI, Gianfranco. As di-versões visíveis das imagens infantis. Pro-Posiçôes, Campinas, SP, v. 22, n. 2, p. 21-37, maio/ago. 2011. 


\section{"Girls don't draw cars...but there are girls who do it": child cul- tures, gender relations and comics}

\section{Abstract}

This article discusses child culture-oriented productions based on the experience of boys and girls aged 3-5 with the language found in comics, focusing on gender relations. It views comics as one of the media products which can interfere in children living style, many times reinforcing sexual differentiation stereotypes. It also examines, in association with philosophy, sociology, sociology of childhood, early childhood pedagogy and art, how children interpret comics and what they reproduce of, invent or reinvent from them. It shows a case study conducted at kindergarten, in the Great $\mathrm{ABC}$ region, which had as methodological procedures: the field observation and recordings; the oral reports of children; analysis of the official documents of the Municipal Administration of Education and of the preschool; an interview with a comic artist, and analysis of comics produced by children. It supports that boys and girls actively take part in the society in which they live. In fact, not only do they imitate the adult world culture, but by absorbing it collectively and creatively, they produce child cultures. It demonstrates that comics are part of the material culture of childhood, that function as a support for the symbolic aspects of children cultures to be shared between kids and among them and the adults. This way, it indicates the challenge of bringing up the children to the debate about the relation between childhood, media and gender, with the aim of under-

\section{"Las niñas no dibujan coches... pero hay niñas que los dibujan": culturas infantiles, relaciones de género e historietas}

\section{Resumen}

Este artículo discute la producción de las culturas infantiles a partir de las experiencias de niños y niñas de 3 a 5 años de edad con el lenguaje de las historietas (comics), teniendo como foco las relaciones de género. Reconoce las historietas como una de las producciones mediáticas que interfiere en la manera de vivir de los niños, muchas veces reforzando estereotipos fundados en las diferencias sexuales. De esta manera, en una interlocución con la filosofía, sociología, sociología de la infancia, pedagogía de la infancia y el arte, problematiza como los niños se apropian de las historietas, lo que de ellas reproducen, inventan o reinventan. Se trata de un estudio de caso realizado en un Jardín de Infantes municipal ubicado en la región del Grande ABC Paulista, Brasil, cuyos procedimientos metodológicos fueron: la observación y el registro de campo; los informes orales de los niños; el análisis de los documentos oficiales de la Red de Educación Municipal y preescolar; entrevista con el cómic; y el análisis de los cómics producidos por los niños. Defiende que los niños y niñas participan de manera activa en la sociedad a la cual pertenecen, y que no reproducen solamente la cultura del mundo adulto, pero al apropiarse colectiva e individualmente de ésta producen las culturas infantiles. Demuestra que las historietas son parte de la cultura material de la infancia, que se constituye en soportes para aspectos simbólicos de las cultu- 
standing how they enjoy, produce and go beyond the media images.

Keywords: Childhood. Gender. The Media. ras infantiles, que los niños comparten entre sí y con los adultos, donde se observan patrones y valores de identidad siendo negociados; eso revela que ellas no sólo reproducen estereotipos de la cultura normativa heterosexual, sino que también infringen las fronteras de género. En ese sentido, apunta para el desafío de traer los niños para el debate acerca de la relación “infancias, media y género", en la perspectiva de (re)conocer como ellas disfrutan, producen y van más allá de las imágenes mediáticas.

Palabras claves: Infancia. Relaciones de Género. Medios de Comunicación. 
Marta Regina Paulo da Silva E-mail:martarps@uol.com.br

Recebido em: 4/12/2014 Aprovado em: 25/6/2015 